\title{
Mild antihyperglycaemic activity in Eclipta alba, Berberis aristata, Betula utilis, Cedrus deodara, Myristica fragrans and Terminalia chebula.
}

\author{
Rehan Ahmad ${ }^{1}$, Swayam Prakash Srivastava ${ }^{1}$, Rakesh Maurya ${ }^{2}$ S.M. Rajendran ${ }^{3}$, K.R. Arya ${ }^{3}$ \\ and Arvind K. Srivastava ${ }^{1}$ * \\ ${ }^{1}$ Divisions of Biochemistry, ${ }^{2}$ Medicinal Chemistry and ${ }^{3}$ Botany, Central Drug Research \\ Institute, Lucknow-226001, India. \\ drarv1955@yahoo.com; \\ swayam.cdri@gmail.com
}

Abstract : The ethanolic extracts of different parts of the following plants viz. Eclipta alba Hassk (Asteraceae) whole plant, roots of Berberis aristata DC (Berbidaceae), stem wood of Betula utilis D. Don (Betulaceae), stem wood of Cedrus deodara (Pinaceae), and fruits of Myristica fragrans Houtt. (Myristcaceae) exhibited 7.5, 8.3, 9.2, 6.0, and $8.7 \%$ significant fall in blood glucose profile in a single dose experiment on Streptozotocin-induced diabetic rats. In single dose experiment nearly $8.0 \%$ decline in blood glucose profile of Streptozotocininduced diabetic rats was observed with a known antidiabetic ethanolic extract of the fruits of Terminalia chebula(Gaern.) Retz (Combretaceae).

Key Words. Antidiabetic plants, antihyperglycaemic activity, streptozotocin, diabetes, animal models.

Introduction

Diabetes mellitus is the commonest endocrine disorder that affects more than 100 million people worldwide. Diabetes mellitus is a state of (almost) permanent hyperglycemia; either a fasting level of $7.0 \mathrm{mM}$ or non-fasting levels of over $11.1 \mathrm{mM}$ are sufficient for the diagnosis (ADA, 1997). Complications of diabetes mellitus are the major cause morbidity and mortality. Plants have always been an exemplary source of drugs and many of

Table 1. Details of plants and their antihyperglycaemic activity.

\begin{tabular}{|l|l|l|l|}
\hline $\begin{array}{c}\text { Plant Name } \\
\text { and part used }\end{array}$ & $\begin{array}{l}\text { Place of } \\
\text { Collection }\end{array}$ & $\begin{array}{l}\text { Month of } \\
\text { Collection }\end{array}$ & $\begin{array}{l}\text { Antihyperg- } \\
\text { lycaemic } \\
\text { Activity (\%) }\end{array}$ \\
\hline Eclipta alba(PL) & October & $\begin{array}{l}\text { Lucknow, } \\
\text { U.P. }\end{array}$ & $7.5^{\star *}$ \\
\hline $\begin{array}{l}\text { Berberis } \\
\text { aristata (Root) }\end{array}$ & May & $\begin{array}{l}\text { Almora, } \\
\text { Uttranchal }\end{array}$ & $8.3^{* * *}$ \\
\hline $\begin{array}{l}\text { Betula utilis } \\
\text { (Stem Wood) }\end{array}$ & May & $\begin{array}{l}\text { Bageshwar } \\
\text { Uttranchal }\end{array}$ & $9.2^{* *}$ \\
\hline $\begin{array}{l}\text { Cedrus deodara } \\
\text { (Stem Wood) }\end{array}$ & June & $\begin{array}{l}\text { Ranikhet, } \\
\text { Uttranchal }\end{array}$ & $6.0^{* * *}$ \\
\hline $\begin{array}{l}\text { Myristica } \\
\text { fragrans (Fruits) }\end{array}$ & October & $\begin{array}{l}\text { Kanyakumari } \\
\text { Tamil Nadu }\end{array}$ & $8.7^{\star * *}$ \\
\hline $\begin{array}{l}\text { Terminalia } \\
\text { chebula (Fruits) }\end{array}$ & March & $\begin{array}{l}\text { Mahabaleswar, } \\
\text { Maharashtra }\end{array}$ & $8.0^{* * *}$ \\
\hline${ }^{*} \mathrm{p}<0.05,{ }^{* *} \mathrm{p}<0.01,{ }^{* * *} \mathrm{p} 0.001$ \\
\hline
\end{tabular}

the currently available drugs have been derived directly or indirectly from them. Several such plants have shown antidiabetic activity using various animal models (Gupta et al., 2005; Pari \& Amarnath Satheesh, 2004; Rajasekaran et al., 2004; Upadhya et al., 2004). A wide array of plant derived active principles representing numerous chemical compounds has demonstrated activity with their possible use in the treatment of Type 2 diabetes (Jachak, 2002; Pari \& Latha,2004). Even the discovery of widely used hypoglycemic drug metformin came from the traditional approa ch of using Galega officinalis. Thus plants are a potential source of antidiabetic drugs (and others too) but this fact has not gained enough momentum in the scientific community. Though development of modern medicine resulted in the advent of modern pharmacotherapeutics including insulin, biguanides, sulfonylureas and thiazolidinediones (Bailey, 1999) there is still a need to look for new drugs as none of the drug (except strict glycaemic control with insulin) has been shown to modify the course of diabetic complications. Many plant species are known in folk medicine of different cultures to be used for their hypoglycaemic properties and therefore used for the treatment of diabetes mellitus. The beneficial multiple activities like manipulating carbohydrate metabolism by various mechanisms, preventing and restoring the function of $\beta$-cell insulin releasing activity, improving glucose uptake and utilization and the antioxidant properties present in medicinal plants offer exciting opportunities to develop them into novel therapeutics. The present report describes the antihyperglycaemic activity in the ethanolic extracts of the plant of Eclipta alba, root of Berberis aristata, stem wood of Betula utilis, stem wood of Cedrus deodara, and fruit of Myristica fragrans.

Materials and Methods

Plant material

The above-mentioned parts of the plants were collected from different phytogeographical region of India during the month of October, May, May, June, October and March respectively (Table 1 ). Taxonomic identification 
of the parts of the plant was established. The collection details and representative voucher specimens of each plant have been documented in

Fig. 1. Antihyperglycemic effect of ethanolic extract of whole plant of Eclipta alba in streptozotocin-induce diabetic rats.

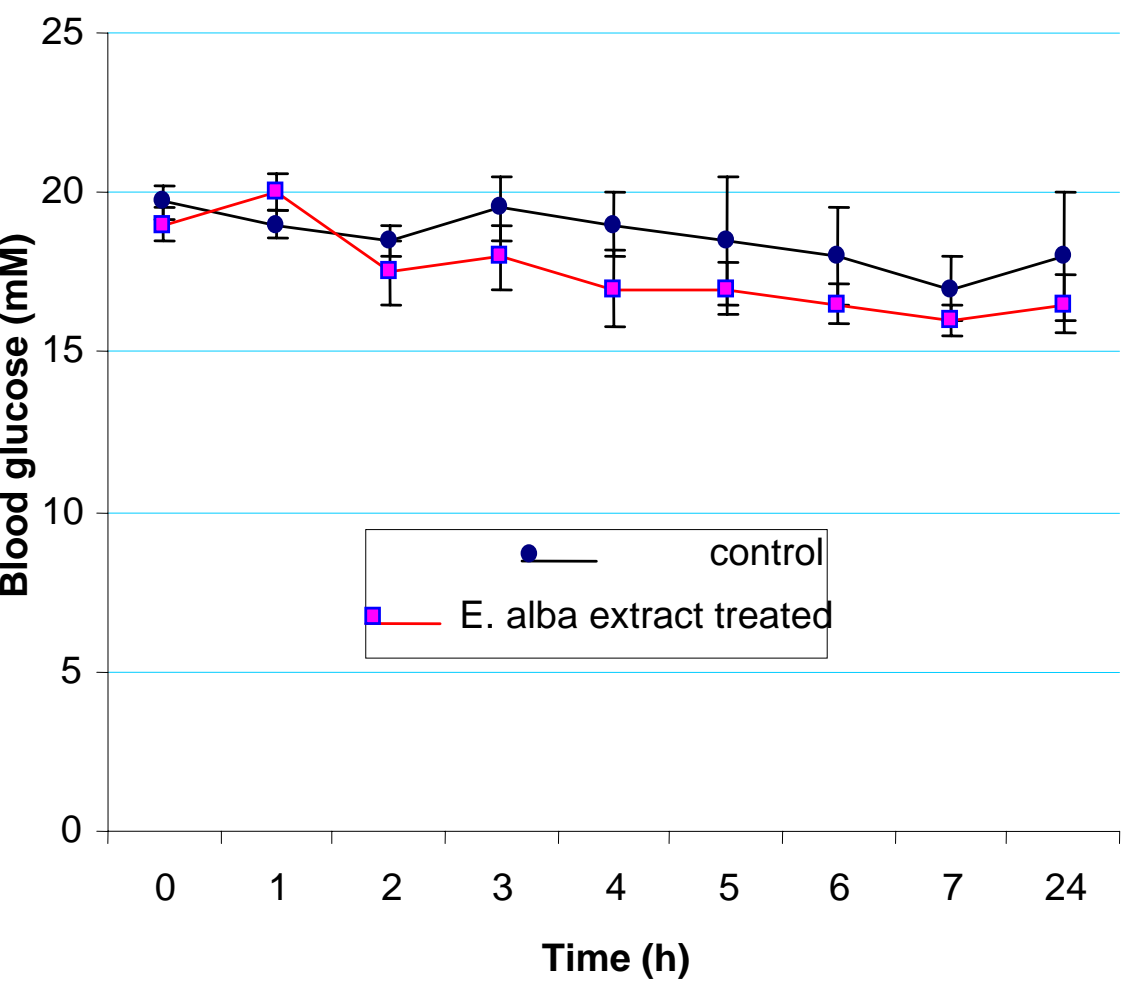

Fig.2. Antihyperglycemic effect of ethonolic extract of whole plant Berberis aristata in Streptozotocin induced diabetic rats.

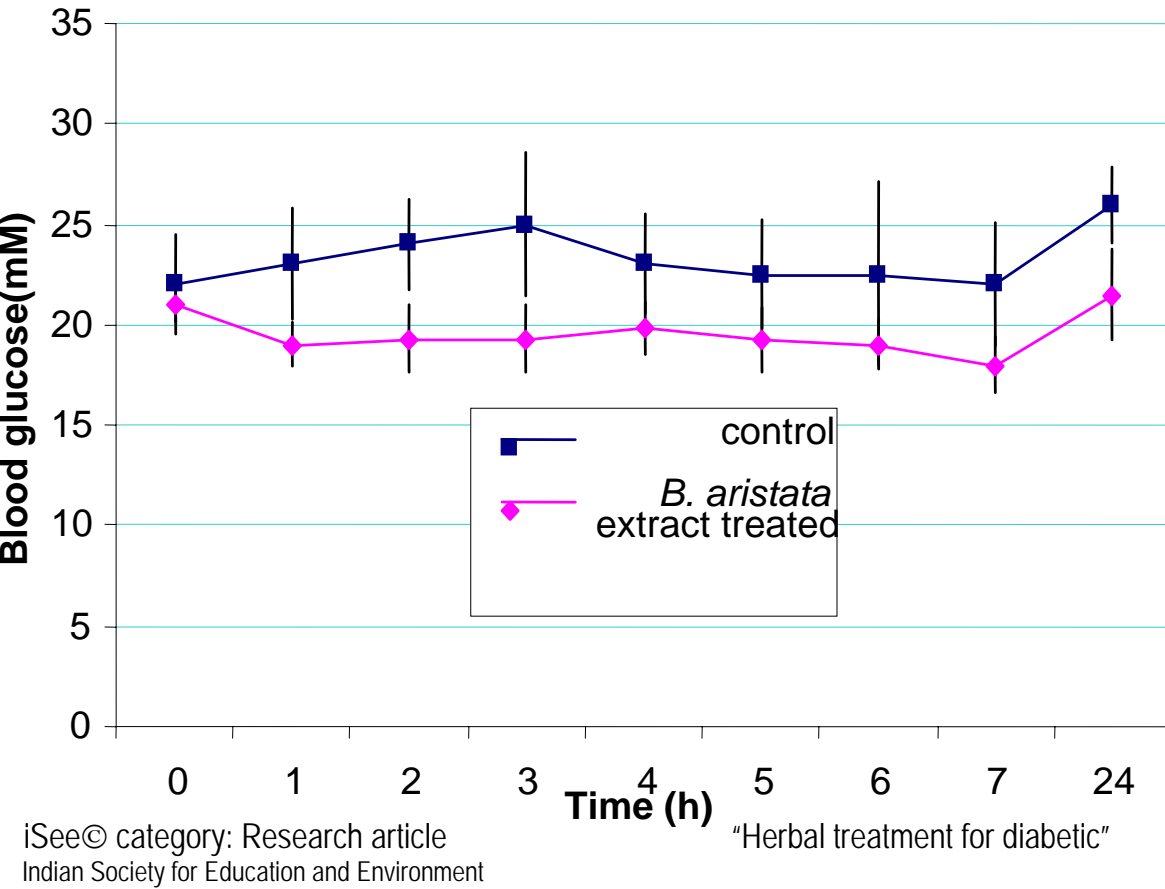

the herbarium of this institute for future reference. The plants were shade dried, pulverized by a mechanical grinder and passed through 100 mesh sieve and stored in a tightly closed container for further use.

Preparation of ethanolic extracts

Air dried parts of the plants were extracted five times with 95\% ethanol (one extraction in one day) at room temperature by percolation method. The combined extracts were evaporated to dryness in vacuum to afford the desired residue. The analytical HPLC (reverse phase) of each sample was performed to obtain residue fingerprint. Effect of ethanolic extract on streptozotocin-induced diabetic rats

Each batch of 40 male Sprague Dawley rats (140$180 \mathrm{~g}$ ) was made diabetic by a single intraperitoneal injection of $60 \mathrm{mg} / \mathrm{kg}$ body weight of streptozotocin (30 $\mathrm{mg} / \mathrm{ml}$ in citrate buffer, $\mathrm{pH}$ 4.5). Two days later blood samples were drawn from tail vein and glucose levels were determined to confirm the induction of diabetes (> $250 \mathrm{mg} / \mathrm{dl}$ ). The diabetic rats were divided into three groups. Control rats (Group I), were given $1.0 \%$ gum acacia, orally, while the test plant extract and standard antidiabetic drug glibenclamide were given to the second and third groups at 250 and $100 \mathrm{mg} / \mathrm{kg}$ body weight, respectively. Blood samples were collected just prior to and 1, 2, 3, 4, 5, 6, 7 and $24 \mathrm{~h}$ after treatment. Food but not water was withheld from the cages during the experimentation. The $\%$ fall in blood glucose values from 1 to 24 hours by

by Rehan Ahmad et al. Indian J.Sci.Technol. 
Fig.3. Antihyperglycemic effect of ethonolic extract of stem wood of

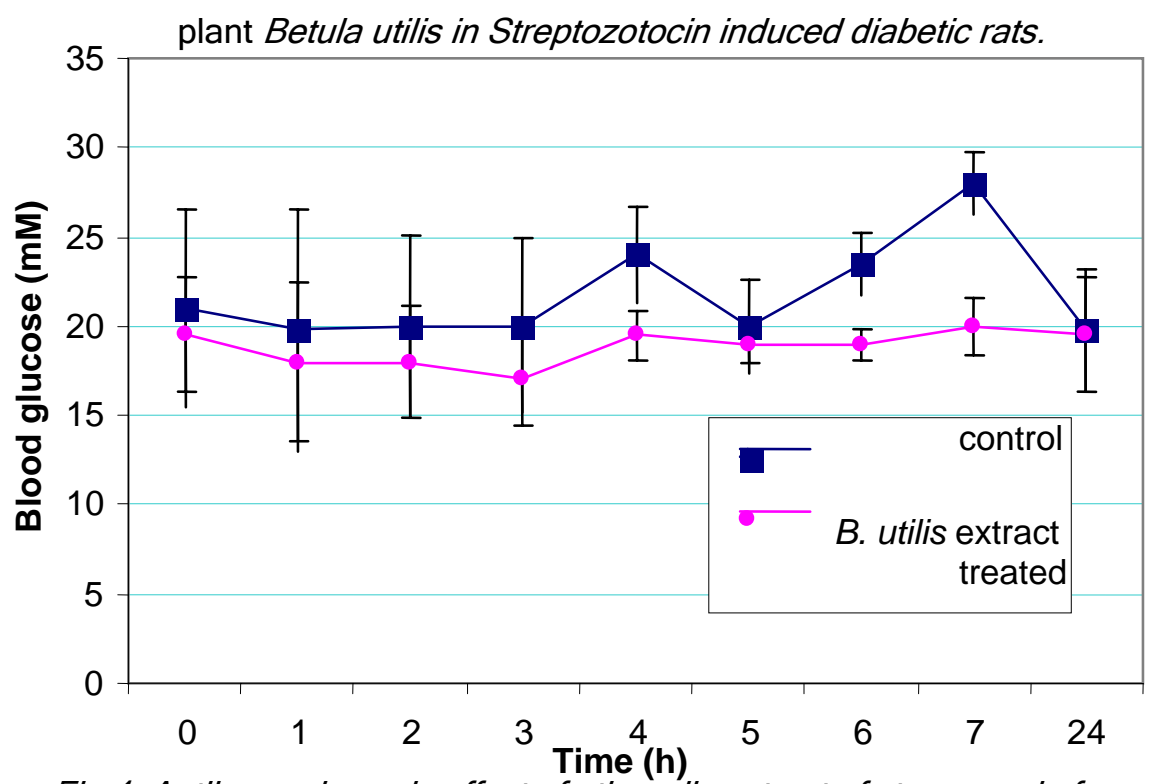

Fig.4. Antihyperglycemic effect of ethonolic extract of stem wood of

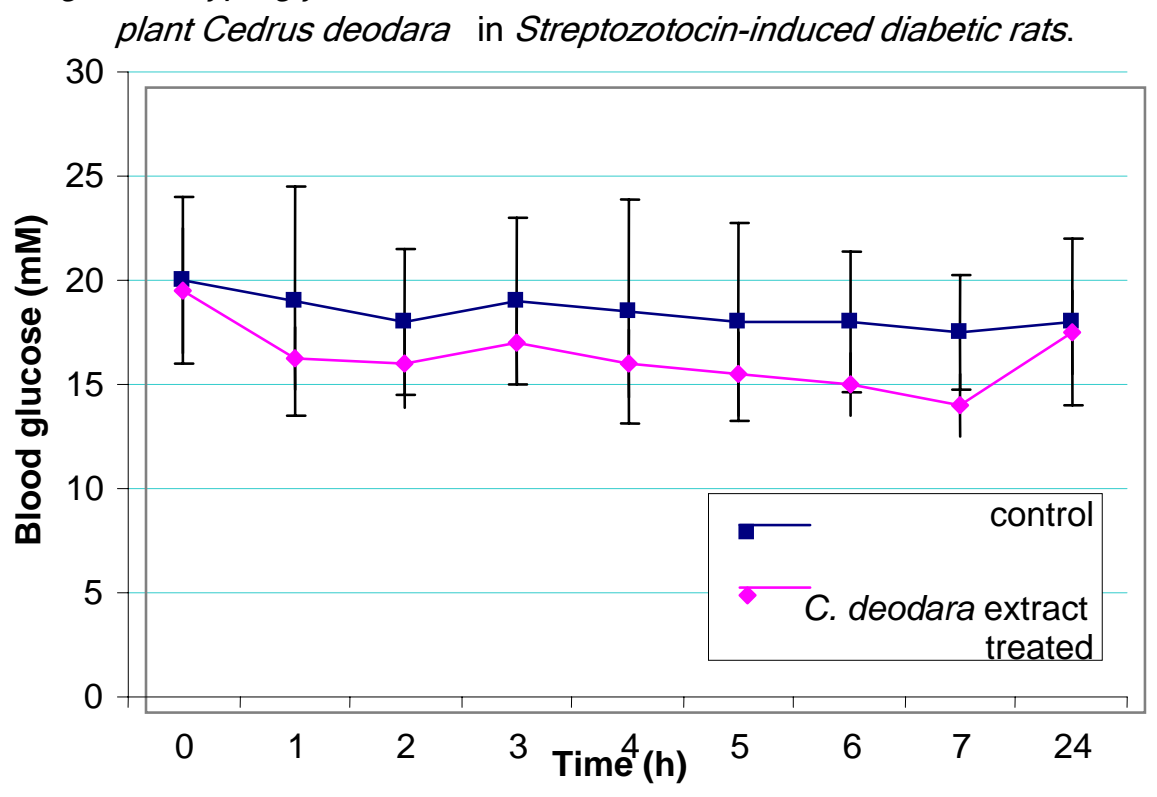

streptozotocin induced diabetic rats during 1 to 24 hours post treatment at 250 $\mathrm{mg} / \mathrm{kg}$ body weight. Fig. 1 depicts the lowering in blood glucose ethanolic extract of Eclipta alba. The peak lowering was found to be from 2 to $7 \mathrm{~h}$. The ethanolic extract of the roots of Berberis aristata showed almost similar type of antihyperglycaemic activity (Fig. 2). The ethanolic extract of the stem wood of Betula utilis was also found to possess antihyperglycaemic activity on STZ-induced diabetic rats as shown in Fig. 3. Administration of ethanolic extract of the stem bark of Betula utilis was found to decline blood glucose level from 1 to $3 \mathrm{~h}$ in diabetic rats as compared to diabetic control. The maximum decline in blood glucose was noted at $3 \mathrm{~h}$ post treatment. It is evident from the Fig. 4 that the ethanolic extract of stem wood of Cedrus deodara exhibited antihyperglycaemic activity on Streptozotocin-induced diabetic rats from 1 to $7 \mathrm{~h}$. Maximum lowering in blood glucose was found to be at $7 \mathrm{~h}$ post treatment. Fig. 5 shows the antihyperglycaemic activity of the ethanolic extract of the fruits of Myristica fragrans on STZ-induced diabetic rats. Administration of ethanolic extract of this part of the plant plant extracts were calculated according to the area under curve (AUC) method. The average fall in AUC in experimental group compared to control group was always termed as \% antihyperglycaemic activity. Statistical analysis was done by Dunnet's test.

\section{Results}

Table 1 presents the average antihyperglycaemic activity profile of the ethanolic extracts of the plant of Eclipta alba, root of Berberis aristata, stem wood of Betula utilis, stem wood of Cedrus deodara and fruits of Myristica fragrans on to STZ-induced diabetic rats resulted in moderate lowering in blood glucose. Lowering in blood glucose was found to be from 3 to $7 \mathrm{~h}$ post treatment. Peak lowering in blood glucose was observed at $7 \mathrm{~h}$ post treatment. The lowering in blood profile with a known antidiabetic ethanolic extract of fruits of Terminalia chebula was found to be between 1 to $7 \mathrm{~h}$, peak lowering was observed at $7 \mathrm{~h}$ post extract treatment as shown in Fig. 6. 


\section{Discussion}

Diabetes is possibly world's fastest growing metabolic disease, so does now there is an urgent need for more appropriate therapies (Ashok \& Madhushudana, 2002). India being country with rich plant diversity, its herbs can be used as curative remedies against diabetes. Diabetes mellitus has been treated orally with herbal remedies based on folk medicine since ancient times in India (Modak et al., 2007). In experiment with many animal species (Rakieten et al., 1967), streptozotocin (STZ) produces permanent diabetes that mimic the pathological status found in human diabetes (Larson et al., 2002). Therefore streptozotocininduced diabetes is reproducible, convenient and can produce diabetes of graded severity suitable for experimental diabetes (Srinivasan \& Ramarao, 2007). In the light of the above reports, an attempt was made to study the effect of selected indigenous plants in lowering blood glucose level on STZ-induced diabetic rats. It is evident from the result that the ethanolic extract of whole plant of Eclipta alba was observed to have significant blood glucose lowering effect on streptozotocin- induced diabetic rats, which has earlier been reported to possess hepatoprotective activity (Saxena et al., 1993; Singh et al., 2001). Administration of alcoholic extract of roots of Berberis aristata has shown mild blood glucose lowering Fig.5. Antihyperglycemic effect of ethonolic extract of fruit of

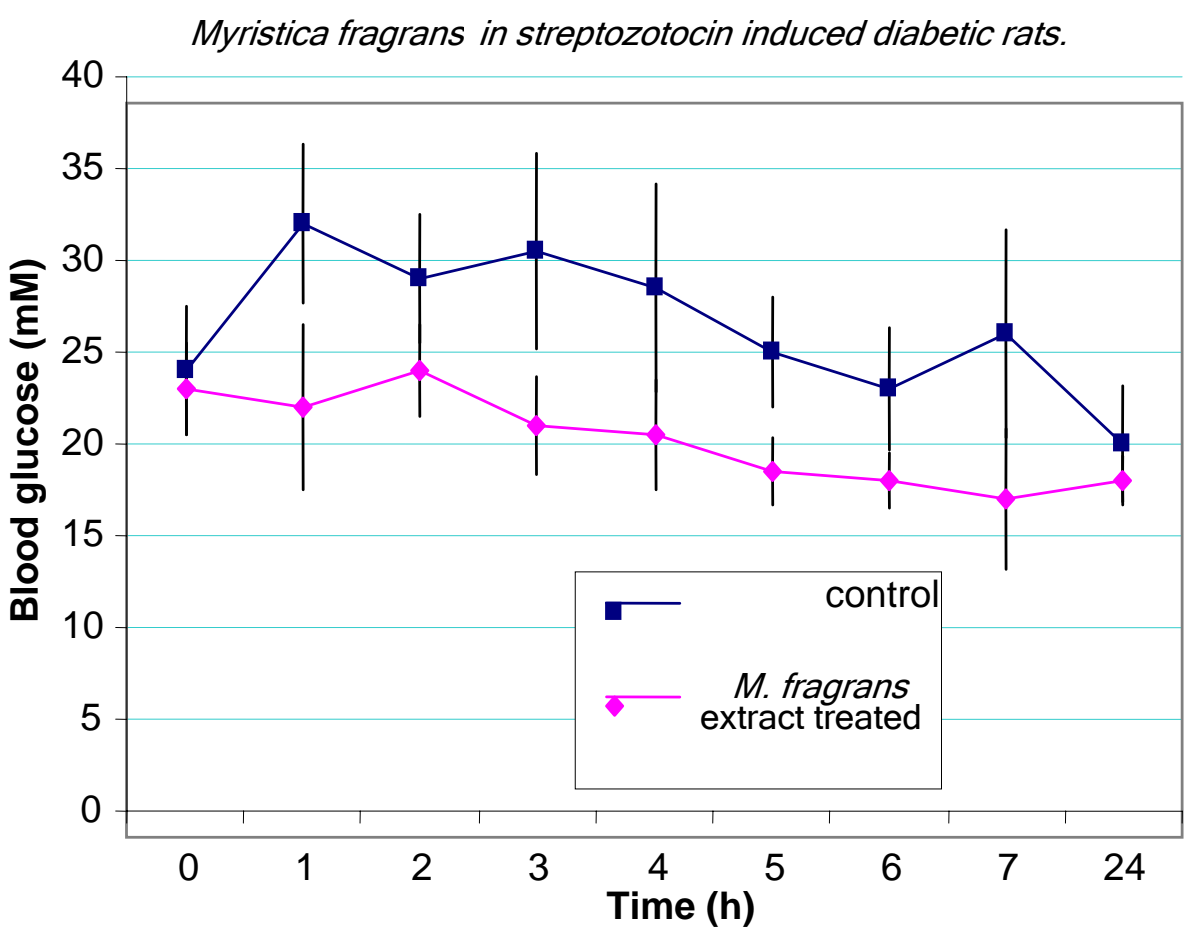

Fig.6. Antihyperglycemic effect of ethonolic extract of fruits of

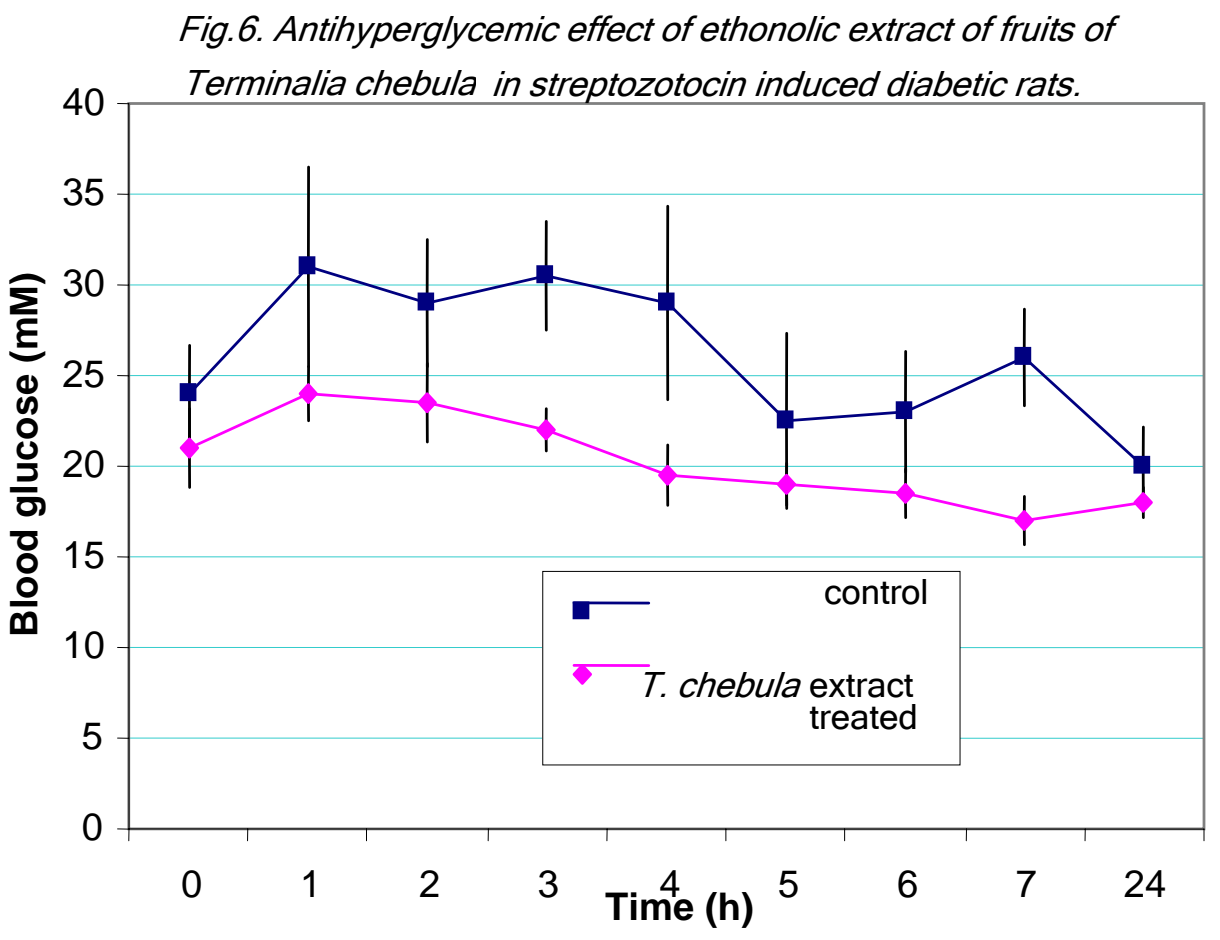

activity on STZ-induced diabetic rats. This plant also possesses anticancer activity (Anis et al., 2001). The ethanolic extract of the stem wood of Betula utilis mildly helped in the decline of blood

Myristica fragrans in streptozotocin induced diabetic rats.

"Herbal treatment for diabetic"

by Rehan Ahmad et al. Indian J.Sci.Technol. 
glucose of STZ-induced diabetic rats, this is first ever report of this plant to possess antihyperglycaemic potential on STZ-induced diabetic rats, although it was found to cause respiratory allergy (Singh \& Kumar, 2002). The ethanolic extract of the stem wood of Cedrus deodara was observed antihyperglycaemic in nature as it showed lowering in blood glucose level of STZ-induced diabetic rats which has earlier been reported to have free radical scavenging (Tiwari et al., 2001), anti-inflammatory and analgesic activities (Shinde et al., 1999). The ethanolic extract of fruits of Myristica fragrans also proved to possess antidiabetic potency as it helped in the decline of blood glucose levels of STZ-induced diabetic rats, which earlier have been reported for hypolipidemic (Ram et al., 1996), antihypercholesterolemic and anxiogenic activities (Sonavane et al., 2002). The ethanolic extract of the fruits of a well-known antidiabetic plant Terminalia chebula, when administered to STZ-induced diabetic rats declined the blood glucose level of rats. Terminalia chebula has also been reported for wound healing property (Suguna et al., 2002), antidiabetic activity (Sabu \& Kuttan, 2002) and anticancer activity (Saleem et al., 2002).

The mode of action of the ethanolic extracts of the selected portion of the above said plants in bringing about the antihyperglycaemic effect has not been studied. It may be urged that at the studied dose the ethanolic extracts of these plants are more potent blood glucose lowering agents in hyperglycemic conditions, with further studies, may be converted into blood sugar lowering agents without the fear of hypoglycaemic shock and other side effects. It is therefore, now unequivocally established that chemical constituents of these plants have mild antihyperglycaemic action with probable mechanism involving insulin secretagogues (like glybenclamide) or having insulin like components.

\section{Conclusion}

The results of the present study have shown that ethanolic extract of Eclipta alba, Berberis aristata, Betula utilis, Cedrus deodara, and Myristica fragrans possess mild antihyperglycaemic effect on streptozotocininduced diabetic rats. These plants may be added to the growing list of antihyperglycaemic plants. Most likely it exerts multiple effects involving both pancreatic and extra pancreatic mechanism. The marked and prolonged activity necessitates a more comprehensive chemical and pharmacological investigation to elucidate the exact mechanism and to isolate and identify its active principle(s). Its toxic effect needs to be understood within the pharmacological framework.

\section{Acknowledgement}

We are grateful to Director, CDRI, Lucknow for his keen interest in this study. Financial assistance from CSIR New Delhi, in the form of Junior Research Fellowship is greatly acknowledged.

References

1. ADA Clinical practice recommendation (1997) Screening for diabetes. Diabetes Care, 20 (1), 22-24.

2. Anis KV, Rajesh kumar NV and Kuttan R (2001) Inhibition of chemical carcinogenesis by berberine in rats and mice. J. Pharm. Pharmacol, 53, 763-768.

3. Ashok TK and Madhushudana RJ (2002) Diabetes mellitus and multiple therapeutic approach of phytochemicals: Present status and future prospects. Curr. Sci, 83(1), 30-38.

4. Bailey CJ (1999) Insulin resistance and antidiabetic drugs. Biochem. Pharmacol. 58, 1511-1520.

5. Gupta RK, Kesari AN, Murthy PS, Chandra R, Tandon V and Watal G (2005) Hypoglycemic and hypoglycemic effect of ethanolic extract of leaves of Annona squamosa L. in experimental animals. J. Ethnopharmacol. 99, 75-81.

6. Jachak SM (2002) Herbal drug as antidiabetics. An overview. CRIPS. 3, 2.

7. Larson MO, Wilken M, Gotfredsen CF, Carr RD, Svendsen O and Rolin B (2002) Mild streptozotocin diabetes in the Gottingen minipig. A novel model of moderate insulin deficiency and diabetes. Am. J. Physiol. Endocrinol. Metab. 282, E1342-51.

8. Modak M, Dixit, P, Lodhe, J, Ghaskadbi, S and Devasagayam TPA (2007) Indian Herbs and Herbal Drugs Used for the Treatment of Diabetes. J. Clin. Biochem. Nutr., 40, 163-173.

9. Pari L and Amarnath Satheesh M (2004) Hypoglycemic activity of Boerhaavia diffusa L.: effect on hepatic key enzymes in experimental diabetes. J. Ethnopharmacol. 91, 109-113.

10. Pari $L$ and Latha $L$ (2004) Protective role of Scopari dulcis plant extract on brain antioxidant status and lipid peroxidation in STZ diabetic male wistar rats. BMC Compliment Altern. Med. 4, 16.

11. Rajasekaran S, Sivagnanam K, Ravi K and Subramanian S (2004) Hypoglycemic effect of Aloe vera gel on streptozotocin-induced diabetes in experimental rats. J. Medicinal Food. 7, 61-66. 
12. Rakieten $\mathrm{N}$, Rakieten $\mathrm{ML}$ and Nadkarni $\mathrm{MV}$ (1967) Diabetogenic action of streptozotocin. Proc. Soc. Exp. Biol. Med. 126, 201-205.

13. Ram A, Lauria $P$, Gupta $R$ and Sharma VN (1996) Hypolipidaemic effect of Myristica fragrans fruit extract in rabbits. $J$. Ethnopharmacol. 55(1), 49-53.

14. Sabu MC and Kuttan R (2002) Anti-diabetic activity of medicinal plants and its relationship with their antioxidant property. J. Ethnopharmacol. 81(2), 155-60.

15. Saleem A, Husheem M, Harkonen $P$ and Pihlaja K (2002) Inhibition of cancer cell growth by crude extract and the phenolics of Terminalia chebula retz. fruit. J. Ethnopharmacol. 81(3), 327-36.

16. Saxena AK, Singh B and Anand KK (1993) Hepatoprotective effects of Eclipta alba on subcellular levels in rats. J. Ethnopharmacol. 40(3), 155-61.

17. Shinde UA, Phadke AS, Nair AM, Mungantiwar AA, Dikshit VJ and Saraf MR (1999) Studies on the anti-inflammatory and analgesic activity of Cedrus deodara (Roxb.) Loud wood oil. J. Ethnopharmacol. 65(1), 2127.

18. Singh $A B$ and Kumar $P$ (2002) Common environmental allergens causing respiratory allergy in India. Indian J. Paediatrics. 69 (3), 245-250.

19. Singh B, Saxena AK, Chandan BK, Aganval $\mathrm{SG}$ and Anand KK (2001) In vivo hepatoprotectfve activity of active fraction from ethanolic extract of Eclipta alba leaves. Indian J. Physiol. Pharmacol. 45(4), 435-41.

20. Sonavane GS, Sarveiya VP, Kasture VS and Kasture SB (2002) Anxiogenic activity of Myristica fragrans seed. Pharmacol. Biochem. Behav. 71 (1-2), 239-44.

21. Srinivasan K and Ramarao P (2007) Animal model in type 2 diabetes: An overview. Indian J. Med. Res. 125, 451-472.

22. Suguna $L$, Singh $S$, Sivakumar $P$, Sampath $P$ and Chandrakasan G (2002) Influence of Terminalia chebula on dermal wound healing in rats. Phytotherapy Res. 16(3), 227-31.

23. Tiwari AK, Srinivas PV, Kumar SP and Rao JM (2001) Free radical scavenging active component from Cedrus deodara. J. Agri. Food Chem. 49 (10), 4642-4645.

24. Upadhya S, Shanbhag KK, Suneetha G, Balachandra Naidu M and Upadhya S (2004) A study of hypoglycemic and antioxidant activity of Aegle marmelos in alloxan induced diabetic rats. Indian J. Physiol. Pharmacol. 48, 476-480. 